\title{
THE DEPICTION OF WOMEN'S SUFFRAGE IN TURKEY IN THE EDITORIAL CARTOONS OF THE ERA
}

\author{
Türkiye'de Kadınlara Oy Hakkı Verilişinin Dönemin Editoryal \\ Karikatürlerinde Tasviri
}

Gökçen Başaran İnce, Ege University, Turkey, gokcenbasaran@gmail.com

\begin{abstract}
For the peripheral modernisation projects, women have oftenly been the face of a rapidly modenising nation, shifting it from one civilisation to the other. The body of the women, its presentation and limits have always had connotative meanings, circumscribing their individuality within the identity of a nation. These assumptions are also valid for the modernisation case in Turkey in which women represented a vast transformation toward a Western and secular society. Granting of the suffrage rights was a historical moment in this process, referring to women becoming public personalities vested with political rights. Yet, this political process was also replete with a social and cultural background in which a new phase of neo-patriarchy endured. The aim of this article is to pursue the vestiges of this representation in the editorial cartoons of the era.
\end{abstract}

Key words: Editorial cartoon, women's suffrage, Turkish modernisation, Women's Union, Nezihe Muhiddin.

Öz: Periferal modernleşme projelerinde, kadın genelde, hızla modernleşen toplumun geçirdiği medeniyet değişikliğinin yüzü olagelmiştir. Kadın bedeninin temsil ve sınırlarının, kadın bireyselliğini, toplumun varoluş biçimine hapseden yan anlamları vardır. Bu varsayım, kadının Batılı ve seküler bir topluma geçişi temsil ettiği, Türkiye'deki modernleşme deneyimi için de geçerlidir. Kadınlara oy hakkı tanınması ise, kadının politik haklarla tanımlanmış, kamusal bir varlık haline gelişini sağlayan tarihsel bir dönemdir. Ancak bu dönüşüm, içinde patriarkal anlayışın yeni biçimlerini barındıran, sosyal ve kültürel bir ardalanla maluldur. Bu çalışmanın amacı, bu algının dönem karikatürlerindeki izini sürmektir.

Anahtar kelimeler: Editoryal karikatür, kadınlara oy hakkı tanınması, Türk modernleşmesi, Kadın Birliği, Nezihe Muhiddin.

\section{Introduction}

Throughout its history, cartoons have been used both as a tool for propaganda and opposition. The power of the visual over the text, the ability to convey complex messages by simple symbols and metaphors, the chance to reach to the illiterate as well as the literate have been the advantages of this medium. Its publication in the newspapers has also facilitated the dissemination of its messages to the masses through a medium which was a tool itself in the creation of the nations (see Anderson 2006).

As for the case of modernisation and nation-building in Turkey, the cartoons have been assigned similar roles to that of the ones in Western societies. They became a functional tool of propaganda during the nation-building process (Gencer 2012 and 2013). They also assisted the creation of stereotypes in which the friends and enemies of the nation had been coded. During this period, the transition to a modern and secular society went hand in hand with the cultural and historical memory of the society. Despite the fervent efforts for women's emancipation, the reforms related to the women have been a realm of meaning in which historical memory was transformed to a new form of patriarchy. Settled stereotypes of this ideology held the liberation of women hostage. Women became the face of a modernising and Westernising society by becoming more visible in public life, attaining "men's professions" or voting, yet meanwhile they were expected to act not as individuals but as the missionaries of the nation-building process by being mothers and child rearing for the nation. This was the creation of the "child-woman" (Zihnioğlu 2003), growing with the Kemalist reforms whom was asked to suffice with what the "fathers" gave and serve to the nation within the boarders of the "common good" decided by the political elites. Any independent voice would be stigmatised as a deviation from the national ideology of the nation-builders.

The granting of the suffrage rights in Turkey exemplifies this attitude toward women. The sideline of the women's movement embodied in the Women's Union which was leaded by Nezihe Muhiddin indicates the thin line between being the ally and the enemy of the founding ideology of the regime. The analysis of the depiction of women after the granting of the suffrage rights in the cartoons of the era, enable to see the construction of women's identities and evaluate whether their individualities have been circumscribed within the forms of patriarchy. By scrutinising the cartoons ran in the newspapers when the suffrage rights were granted, this study aims to understand the stereotypes which defined the boundaries of womenhood and women's movement. 


\section{Editorial Cartoons: The Visual Supports of the News}

Cartoons are drawings which depict a specific event or person mostly with a humorous style, using metaphors, symbols, analogies, exaggerations and/or distortions (see Kemnitz 1973). The publication of the cartoons in the newspapers and their address to daily social and political events constitute a sub genre called "editorial cartoons" in which cartoonists back up the editorial policies of the newspapers through the power of the visual. The rise of the editorial cartoons goes hand in hand with the rise of the newspapers and the printing technologies (Lawate 2012, 3). Cuff notes that

Published drawings that are designed to produce a humorous effect and to teach a lesson are editorial cartoons. When a cartoonist creates a sketch that is both pictorial and editorial, he communicates an opinion or a conviction. He reveals a preference for, or a judgment against, some person or class or issue or foible. Both social and political cartoons have been used as editorial vehicles $(1945,87)$.

Editorial cartoons aim to convey ideas or opinions which are shaped by the editorial policy of the newspaper. Another important function of the editorial cartoons is to mold public opinion by simplifying complex ideological messages into easily understandable symbols and metaphors. They have a complemantary mission along with the editorial coloumns of the papers. According to Neighbor et al (2014):

In a newspaper, editorials are articles presenting a columnist's point of view or opinion, so an editorial cartoon is a cartoon that expresses the viewpoint of a cartoonist. Given their similarities, political cartoons and editorials are generally placed in the same section of the newspaper, and their subjects often complement each other.

Editorial cartoons function both in the process of "opinion-molding and opinion-reflecting" (Caswell 2004, 14). It is of importance to note that cartoons are not obliged to be "objective" as the rest of the news in a paper (Bezirgan Arar 2010). They are rife with a biased and constructed form of reality. The real editorial policy of the newspaper may also be transferred to the cartoon time to time because it is able to operate more subjectively. Cartoons can also be used to "advance the interests of the cartoonist, the editorial objectives of the newspaper publishing it, and/or the interests of a politician or a political lobby group that supports the publication" (Mulanda and Khasandi-Telewa 2014, 32). They emanate from the power relations in a given society in which they function both as a means of opposition and/or propaganda. They are also able to convey complex and unutterable messages that can not be expressed by articles or editorials explicitly. The lampooning and ridiculisation of politicians, stereotyping of minority groups are far more possible by using symbols or metaphors rather than words. Through widely used stereotypes, metaphors and symbols, cartoons contribute to the making of social representations (Moloney et al. 2013). They have the ability to anchor settled representations of social groups and substantiate the general agreements on stigmatised groups. A cartoon's success lies in its ability to address the cultural memory of the society (see Wekesa 2012). Cultural memory enables one's penetration into his/her society through the historical and cultural reservoir of knowledge on specific issues. Despite universal symbols, cartoons entail a local set of information in order to effect public opinion.

According to Frantzich (2013), possible cartooning approaches consist of caricature, metaphor, sarcasm/irony, word play and sight gag. Wekesa notes that

A caricature is a picture or other representation that exaggerates the particular physical features, dress or mannerisms of an individual to produce a ludicrous effect. Caricature is commonly used to ridicule political, social or religious situations and institutions, or actions by various groups or classes of a society. Such type of caricature is usually done with satirical rather than humorous intent in order to encourage political or social change $(2012,229)$.

Metaphors enable readers to understand abstract or unfamiliar visual concepts via structural conceptual mappings from more specific and familiar concepts (Wekesa 2012, 226). Common symbols and icons bring about common senses on issues in a society in which cultural memory reservoir functions in the making of meaning. Irony is the difference between the ways things are and the ways things are expected to be (Guity 2014). Word plays enable innuendos in which sarcams/irony foment the public opinion. A sight gag epitomises its message by using visual forms rather than words or captions.

Editorial cartoons are a reduction of an idea, a conclusion without an argument, effective because of succinctness, poignancy, and topicality (Vokey 2000). Cartooning is an art of expressing lenghty messages by single metaphors or symbols. Cartoonists achieve this by condensation and domestication. Vokey notes that

Condensation uses stereotypes and symbolic metaphors in order to reduce complex phenomena or specific events to their apparent shared core via a single image. Domestication converts difficult and unfamiliar ideas into something close and concrete by "highlighting mutual elements and masking unique ones and by focusing on repetitive patterns to minimize novelty and mental adjustment" (Morris 1993 cited by Vokey 2000, 141143). 
All in all one may conclude that cartoons create a specific language system of their own that consists of metaphors, symbols, caricatures and/or other methods like irony or analogy in order to convey messages to mold public opinion. Roland Barthes notes that the meaning has two contexts as denotative and connotative. While literal image is denoted, the symbolic image is connoted $(1977,37)$. According to Barthes:

At the level of the literal message, the text replies - in a more or less direct, more or less partial manner - to the question: what is it? The text helps to identify purely and simply the elements of the scene and the scene itself; it is a matter of a denoted description of the image $(1977,39)$.

Denotative meaning simply refers to the explicit interpretations and identification of a message while connonative meaning guides interpretation and ideology. It consists of symbols, metaphors and analogies. Barthes proposes three strategies to unravel the rhetoric of images (Wekesa 2012, 224-225):

- Textual analysis studies the relationship of the image to its caption.

- Denotation reads the image literally.

- Connotation reads the image mythically and ideologically

Barthes calls the signifiers as connotators and their set as a rhetoric $(1977,49)$. Rhetoric is the persuasive use of language (Wekesa 2012, 224). Rhetorics may be articulated by sound, image, gesture. Analogies also enable the cartoonist to simplify his/her message through likening an issue or person to something else which society may identify with. The cultural memory of the society reduces the discrepancies which may occur in the anologies constructed by the cartoonists.

Moloney et al. (2013) offer some fundamental tools used in the cartoons in the making of social representations: exaggeration, infantilising, physiognomic stereotyping and hyperbole. While working in the denotative and connotative levels, these strategies go hand in hand with the cultural reservoir of the society in the construction of social representations. Cultural and historical attributions, physiognomic stereotypes provide fixed representations of social groups in which identities are reconstructed and substantiated continually. Editorial cartoons articulate the stance of the cartoonist and the newspaper on these groups and construct their images through selected stereotypes.

\section{A Brief Glance at the History of Editorial Cartoons in Turkey}

Editorial cartoons appeared firstly in the nineteenth century Ottoman press. Turkey's rich heritage of traditional homour, like Hacivat-Karagöz and Nasreddin Hodja eased the flourish of cartoons in magazines and press after the Tanzimat and the First Constitutional Era in 1800s. Tunç notes that

In the Ottoman context (1867-1922), the old tradition of shadow puppet theater had been widely used for satirizing the social and political events of the time and the humor had been conveyed within the narrative structure in the 1870s. Later on, the press borrowed these humorous dialogs and adapted them for editorial cartoons $(2002,51)$.

Teodor Kasap (1835-1905) was the first person to hire an editorial cartoonist, when he brought Nisan Berberyan to his humor newspaper, Hayal (Illusion) in 1873, with the purpose of supporting the political stance of his editorial (Tunç 2002, 52). Yet after Abdülhamid dissolved the Parliament in 1878, the editorial cartoon declined and a severe censorship impeded the development of any other publication including the cartoons. Despite the Young Turks' efforts to publish magazines and newspapers abroad, editorial cartoon's rise overlapped with the newspapers' abundance during the second constitutional era after 1908 revolution. Brummett construes this period as a "cartoon revolution" "where images could take precedence over words; where the past, present, and future were created and imagined; where the celebration of new freedoms brought citizens into contact with menaces in the streets" (Brummett 1995). During this era, in addition to the quantity, the quality of the cartoons improved as a result of western influence. Kalem (The Pen, 1908-11) was the most influential publication carrying a variety of cartoons using different techniques. With its bilingual (French and Turkish) structure and relatively higher printing standards, Kalem aimed at the educated population (Tunç 2002, 53). During the period, much of the artwork in the press supported the narrative message or editorial policy of the publisher rather than providing notoriety for the artist (Brummett 1995, 436). Cartoons were mostly unsigned and they were also reprinted from one gazette to another, suggesting that the cartoonists had no property rights as such (Brummett 1995). The main themes of the cartoons during these times were Western influence on the Empire, its effects on women and general menaces the Empire had to deal with, like cholera.

During the national liberation movement in 1920s, cartoon was used as a tool for propaganda. Güleryüz (Smiling Face) and Aydede (Moonlight) were two leading humour magazines of the days. Güleryüz was pro-national movement and supported Mustafa Kemal as "the symbol of the anti-imperialist movement" (Çeviker 1997 cited by Tunç 2002) while Aydede stood against the nationalist cause and supported European intervention (Tunç 2002, 53).

After the establishment of the Republic, cartoon's function as a tool for propaganda endured and the immense reforms were articulated to the masses with the help of the visual. The Regime attempted to reach to the illiterate through visual symbols in which Mustafa Kemal was depicted as a protagonist and hero fighting against backward, 
reactionary movements (see Gencer 2012 and 2013). Religious movements and the Kurdish opposition were the first concerns of the new Regime and they were disparaged in the cartoons of the era by dehumanization and delegitimization.

The printing regime of the early Republican period overlapped with the political atmosphere of the country. After the Kurdish rebellions in 1920s until 1926, Takrir-i Sükûn (Law on the Maintenance of Order) brought about severe cencorship on the press. As the opposition lost its power, the Regime relatively eased off restrictions until the foundation of the Free Republican Party which received an unprecedented support from the society and subsequently the Menemen incidents through which religious opposition was incriminated in killing of a soldier brutally. Press law enacted in 1931 enabled the closure of newspapers and magazines temporarily because of the publication policies which were assumed to be against the general policy of the country. The editorial cartoons probed in this study have also been the products of the mentioned political atmosphere, the printing regime and the historical background.

\section{The Establishment of Women's Suffrage in Turkey}

Scholars working on the history of women's suffrage in Turkey share different ideas on the issue, having discrepancies whether suffrage was granted by the Kemalist elite, or it was deserved by the women themselves after a struggle. The history of Turkish women's activism dates back to the second half of the nineteenth century, the later period of the Ottoman Empire (Ziya et al. 2010). The establishment of women's organizations and magazines are indicated as the first samples of a developing feminist consciousness. That said, Safarian challenges these comments and explains his ideas on the women's organisations of the era as follows:

(...) Those however, had mainly a cultural and educational nature and were not related to the social status of women; therefore, the significance of the mentioned organisations should not be overestimated (...) Practically, in that period, the so-called Feministic activities in the country were concentrated in the capital city and involved only well-to-do and educated women of a very restricted circle that was well isolated from the general public. It is quite true to say that during the Tanzimat, there was no change in the status of women (2007, 141-142).

The end of $1800 \mathrm{~s}$ witnessed important deeds on the education of women. Educations on midwifery and teaching enabled young women to attain professions. Women started to publish magazines (Hantmlara Mahsus Gazete (Newspaper for Ladies) -as a leading and longlasting example published by Fatma Aliye-) and establish organisations working for the "rise" of the Ottoman women. Kadınlık Mefkûresi (Women's Ideal) as a concept brought about the discussions on women's problems, what they wanted to become, the ways to rise their consciousness, their desire to join public life, their will for education and attainment of professions, all in all the way to become a "new person" (see Zihnioğlu 2003, 45). Along with the 1900s, this movement started to articulate its claims loudly on women's liberation, including political and social rights (see Adak 2007; Zihnioğlu 2003). Halide Edip's Teali- Nisvan (Organisation for Women's Rise) appeared as the first feminism oriented organisation. Ulviye Mevlan's Osmanlı Müdafaa-i HukukNisvan Cemiyeti (Ottoman Union for the Defense of Women's Rights) was the first organisation to have the women suffrage rights on its agenda in 1921. The Union also published a leading journal under the title of Kadınlar Dünyası (Women's World) between 1913-1921 (Gökçimen 2008).

A distinguishing difference between the Empire and the Republic stems from the state's role in the process of women's emancipation. Despite the efforts to ameliorate the education system or the enactment concerning women (like granting equal inheritance rights with men in 1847 and 1858), the stance of the elites in the Empire seems to have been relatively more passive than the Kemalists. Kemalism's will to "civilisation" and the efforts to modernise the society bring the women issue into the core of social change. Since the 19th century, there seems to have been agreement among many actors across the world that the status of women indicates civilisational belonging and helps gauge the level of advancement of a society (Towns 2014, 596). Political elites in Turkey also equated the position of women to the level of civilisation which was symbolised by the "West". As Arat notes

The West was a model to be emulated, and the founding fathers of the Republic were keen to become more western than the countries in the West. Thus, the Turks would long teach their children that women received suffrage in Turkey before those in France and Switzerland and would cite statistics on the high (roughly about a third) proportion of women doctors, lawyers and teachers in Turkey that many western countries did not have before the 1970s (Arat 2001, 28).

Along with the establishment of the Republic, a more drastic phase which some scholars named as "state feminism" inaugurated. State feminism can be construed as making the women's equality in the public sphere a national policy (Atakav 2007, 15). Promoting women's emancipation through enactment, encouraging them to unveil and become visual in the public sphere, granting social and political rights are some aspects of state feminism. Yet political elite's active interference in the women issue did not result in the total liberation of women (see Kandiyoti 1987). State feminism is critisized of demanding a "citizen woman", urban and urbane, being socially progressive but lacking in interference to private sphere (see Atakav 2007). Male domination, virginity-fidelity-son producing ethos (Beck and 
Kheddi 1978 cited by Kandiyoti 1987, 319) also endured as a form of "neo patriarchy" (Sharabi 1988 cited by Al Ali 2002) and/or "patriarchal paradox" (Arat 1989) in which despite the amelioration in rights, women's highest duties were defined as childrearing and motherhood, conceptualised as "republican motherhood" (Ziya et al. 2010, 318). Opposing to the idea of "state feminism", Arat notes that

Kemalist reforms were not aimed at liberating women or at promoting the development of female consciousness and feminine identity. Instead, they strove to equip Turkish women with the education and skills that would improve their contributions to the republican patriarchy by making them better wives and mothers. With a goal of socioeconomic development, these reforms are hardly feminist, and their perception of the role of women and definition of womanhood would not qualify them to be taken as "state-sponsored feminism" as done by some analysts $(1994,57)$.

It is also a fact that Kemalist reforms remained a dead issue for a long time, especially in those rural areas most weakly integrated into the national economy (Kandiyoti 1987, 322). The modernisation project had various impasses like bringing about the "emancipation of women in the public sphere (albeit with constricted ideological bounds) and the simultaneous preservation of women's duties/responsibilities in the household" (Ziya et al. 2010). Yet despite the social and economical hindrances and the "neo-partiarchy" which reproduced traditional gender roles during the reforms in the Republican era, it is important to note that

Among the countries of the Middle East, Turkey may be singled out as a republic that has addressed the question of women's emancipation early, explicitly, and extensively. The formal emancipation of Turkish women was achieved through a series of legal reforms following the war of national independence (1918-23) and the establishment by Mustafa Kemal Ataturk of a secular republic out of the remains of the Ottoman state. The adoption of the Turkish Civil Code in 1926, inspired by the Swiss Code, outlawed polygamy, gave equal rights of divorce to both partners, and permitted child custody rights to both parents (Kandiyoti 1987, 320).

Women's suffrage was also one of the notable reforms which enabled women to advance their position in the society and become more visible in the public sphere. It was a point in discussion in the last decade of the Ottoman Empire by the leading feminists of the era like Halide Edip or Nezihe Muhiddin. Adak notes that in the case of Halide Edib, suffrage was an ideal which she desired for Turkey as early as during the aftermath of the Young Turk Revolution. In 1912, the Yeni Turan party in Halide Edib's utopian novel Yeni Turan (New Turan, 1912), a popular work during World War I, granted suffrage to women (Adak 2007, 40).

The women's suffrage was on the agenda in 1923 during the debates on the Intihab-ı Mebusan Kanunu (Law on the Election of Parliament Members). Tunalı Hilmi Bey, deputy of Bolu, positioned in favor of granting electoral rights to women during the debates. In the elections, despite women not being granted their rights of suffrage, leading women in the society such as Latife (Uşşaki), Mevhibe (İnönü), Galibe (Okyar), Müfide Ferit (Tek) and Kara Fatma (a heroine of the national independence war) were among the ones whose names had been counted in the ballots (Özer 2013).

Before the elections, Nezihe Muhiddin attempted to establish Kadınlar Halk Fırkası (Republican Women's Party) in 16 June 1923. The leaders of the Republic, however, rejected the founding of a women's party and recommended the establishment of a women's association instead. According to Zihnioğlu, the elites of the era impeded the foundation of the Kadınlar Halk Firkası for two reasons: Firstly, the "women's rights" issue was the symbol of the modernisation project and the Government wanted to circumscribe the other social and political movements in order to put itself forward. The programme of the Kadınlar Halk Firkasl was construed as an interference to the plans of the Government and women's potential of becoming a pressure group was a point of concern. Secondly, the Kemalists wanted to instrumentalise the discourse of "We granted the women their rights" (see Zihnioğlu 2003, 149). On the other hand, Toprak claims that the Kemalist elites did not want women to get organised as a political party and under the similar title to that of the Party planned to be established by the Kemalist elite. The "Republican People's Party" was to be founded after a short while. A "women" themed organisation was also construed as a "divisive" activity at a time when "unity" was the fundamental target by the political elites of the day (see Toprak 1988, 31).

It was in this context that Türk Kadinlar Birliği (Turkish Women's Union) was founded. The Union was able to be established after the withdrawal of the "famous" second article in which political rights (hukuk-i siyasiyye) were demanded. It was also added to the Union guidelines that "The Union [had] no relevance to the politics". The article which determined the participation to the municipal elections was also withdrawn (Zihnioğlu 2003, 150- 151). Despite these restrictions, the Union aimed at the attainment of suffrage for the women in Turkey and campaigned and lobbied for this among the political elites of the day. For instance the Union nominated Nezihe Muhiddin and Halide Edip as candidates in 1925 elections. This attempt was evaluated as a "propaganda game" by some of the journalists of the day, like Yunus Nadi from Cumhuriyet and was attacked as an effort in vain because of the political climate in Turkey which was profoundly tense due to the Sheikh Said Rebellion. The Union also published a magazine called Kadın Yolu (Woman's Path) between 1925-1927 in which leading intellectuals of the day published their ideas on feminism. In 1926, the members of the Union had recourse to the Republican People's Party to become party members in order to keep the political rights of women on the agenda and warn the "reform government". Yet these efforts were manipulated by some of the journalists of the day and Nezihe Muhiddin was condemned for having political ambitions. 
In 1927, the Union organised a congress, attempted to revise the second article and claimed political rights once more. Along with the "persistent" demands of political rights, a smear campaing against Muhiddin was launched by the press, accusing her of corruption. Before Muhiddin's expulsion, the Union made one more attack for political rights. They would nominate women candidates from the Republican People's Party and this act would be repeated at every election until the political rights were gained. The answer of Ibrahim Tali Bey to this demand, as the deputy president of the Republican People's Party, was negative, claiming that the conditions for women's suffrage were not ready yet. Some of the deputies alleged that this demand was against the constitution. According to them, the deputies were to be "Turkish and man". But the Union did not give up and attempted to propose a change in the constitution. The Union also announced an election declaration, focusing on suffrage and decided to have recourse to the National Assembly to join the municipal elections and become members in the municipal councils. Muhiddin also declared that the Union would support the "pro-women" candidates and nominate men candidates. An important aspect had been the usage of the concept of "feminism" during all these efforts more openly and frequently (see Zihnioğlu 2003, 208-211). As the Union pressed for political rights, the smear campaign in the newspapers soared. The Union openly declared that the women's suffrage was the fundamental reason for the existence of the Union and the members would never give up this ideal (20 July 1927 Cumhuriyet, cited by Zihnioğlu 2003, 219). Yet this "persistence" resulted in the trial of Nezihe Muhiddin after being charged with corruption. Muhiddin was expelled from the Union after a controversial congress held by the opponents. Latife Bekir was elected as the second president of the Union. Bekir opposed the suffrage rights, defining the demand as "running behind dreams" (cited by Zihnioğlu 2003, 205). From 1928 until 1935 -to the date when the Union disbanded itself- political rights were never again mentioned by the Union and its functions diminished to a charity organisation as demanded by the political elites of the day. Despite the activism of the women's movement, as Arat notes

The founding fathers of the Republic nurtured and advocated a unitary, transcendental concept of the common good for the polity. Accordingly, the state or the governing elite knew the best interests of the people. It was assumed that the interests of different groups, men and women as much as peasants and industrialists, were potentially complementary. Societal interests preceded individual interests. The scope for democracy was limited within the constraints of formal equality. Secularism meant state control over religion. This tradition, though it evolved over time, continued into the 1980s (Arat 1998, 129).

Even though the scope of women's activism was limited, the ruling elites of the day wanted to confine the political movements to the sphere of modernisation and Westernisation project leaded by the State. When Mustafa Kemal founded the Turkish Republic in 1920, he initiated what could be called "citizenship from above". Citizens were expected to be passive agents and accept those civil, political and social rights granted to them (Arat 1996, 29). According to the elites, this was a transition period in which alternative projects should have been disbanded. Women like Nezihe Muhiddin who wanted to endure women's movement politically active, was sidelined as in the case of her expulsion from the Union, having been accused of corruption cases. After suffrage was granted to the women in 1930 (municipal elections) and 1934 (general elections), the Women's Union first limited its activities to charity, then disbanded itself, claiming the unnecessity of its mission in 1935 (Zihnioğlu 2003). The Women's Union was perceived as having too much of an independent voice in the public realm, as being sectarian and individualistic, and somehow threatening to the national interest (Arat 2000 cited by Diner et al. 2010). This marked the end of the first wawe feminism in Turkey until the second one soared in 1980s.

\section{The Depiction of Women's Suffrage in the Editorial Cartoons of the Era}

Editorial cartoons provide insight to construe the polical and social climate of the era in which they have been created. Because one of their fundamental aim is to mold public opinion, they reflect the interpretations of events and people created by the cartoonist and the newspaper. Kemnitz notes that

[Cartoons] can give a clear idea of the images politicians projected. They offer contemporary interpretations of events and reveal much of the sense of proportion of their creators. They can give an indication of the depth of emotion about events and politicians. And they can provide insights into the popular attitudes that underlay public opinion, insights that may be more difficult to glean from written material or from other evidence of behavior $(1973,92-93)$.

The analysis of the editorial cartoons in this study also aims to understand the molding of the public opinion and the creation of women's image during the granting of the suffrage rights. It covers one month period before and after the declaration of the rights in 1930 municipal elections. The newspapers of 1934 when suffrage rights for general elections were granted have also been examined but newspapers ran no cartoons on the issue by then. Daily Cumhuriyet, Milliyet and Vakit are the newspapers selected for the analysis. Cumhuriyet and Vakit were the leading newspapers of the Kemalist regime under the direct control of deputies; they also alternated having the highest circulation rates between 1927-1938 (Kocabaşoğlu 1982 cited by Brockett 2011, 61). Milliyet's head coloumnist was 
also stated as "Siirt deputy Mahmut" (Başmuharriri: Siirt Mebusu Mahmut) in the first page of the newspaper. The three newspapers were in favour of the Republican People's Party and they reflected its general policies and tendencies.

The table below shows the number of cartoons published in the newspapers. Cartoons are categorized as the ones directly related to the suffrage rights and the indirect ones that relate to the Women's Union, discussion on the disbanding of the Union and disputes between the Union and Nezihe Muhiddin after the announcement of the suffrage rights:

Table 1: Number and content of the editorial cartoons

\begin{tabular}{|c|c|c|c|}
\hline Newspaper & Direct Cartoons & Indirect Cartoons & Total \\
\hline Cumhuriyet & 6 & 1 & 7 \\
\hline Milliyet & - & 2 & 2 \\
\hline Vakit & 2 & 5 & 7 \\
\hline Total & & & 16 \\
\hline
\end{tabular}

\subsection{Cartoons on the Suffrage Rights: The Women of "Boya and Süs"}

In 1920s, when Muhiddin was campaigning for “equal payment for equal work” and women's attainment of professions which men "naturally" did possess, a cartoon that was published in Akşam resulted in women's protests because it was referring to the "rise of women", of women "boya and süs" (make up and ornament) (see Zihnioğlu 2003, 189). Cumhuriyet also mocked the efforts of women's movement for equal jobs and suffrage rights in the editorial cartoons in which women were depicted discussing the "fashion" and "cloth" of the year in the parliament zealously while men were gazing at them tauntingly (cited by Zihnioğlu 2003, 189-217).

It is hard to say that the women representation in the newspapers changed in 1930s, at least in the ones examined in this study. As the suffrage rights were announced by the Government, sexist depictions and clichés appeared in the cartoons putting forward the sexual traits of women. The patriarchal ideology of the political elites combining with the editorial policies of the newspapers which equated womenhood to giving birth and child-rearing, disparaged women by mocking their gender. This was the reconstruction of the widely shared social representation in which men represented the "ratio" and women the "beauty" and the "elegance".

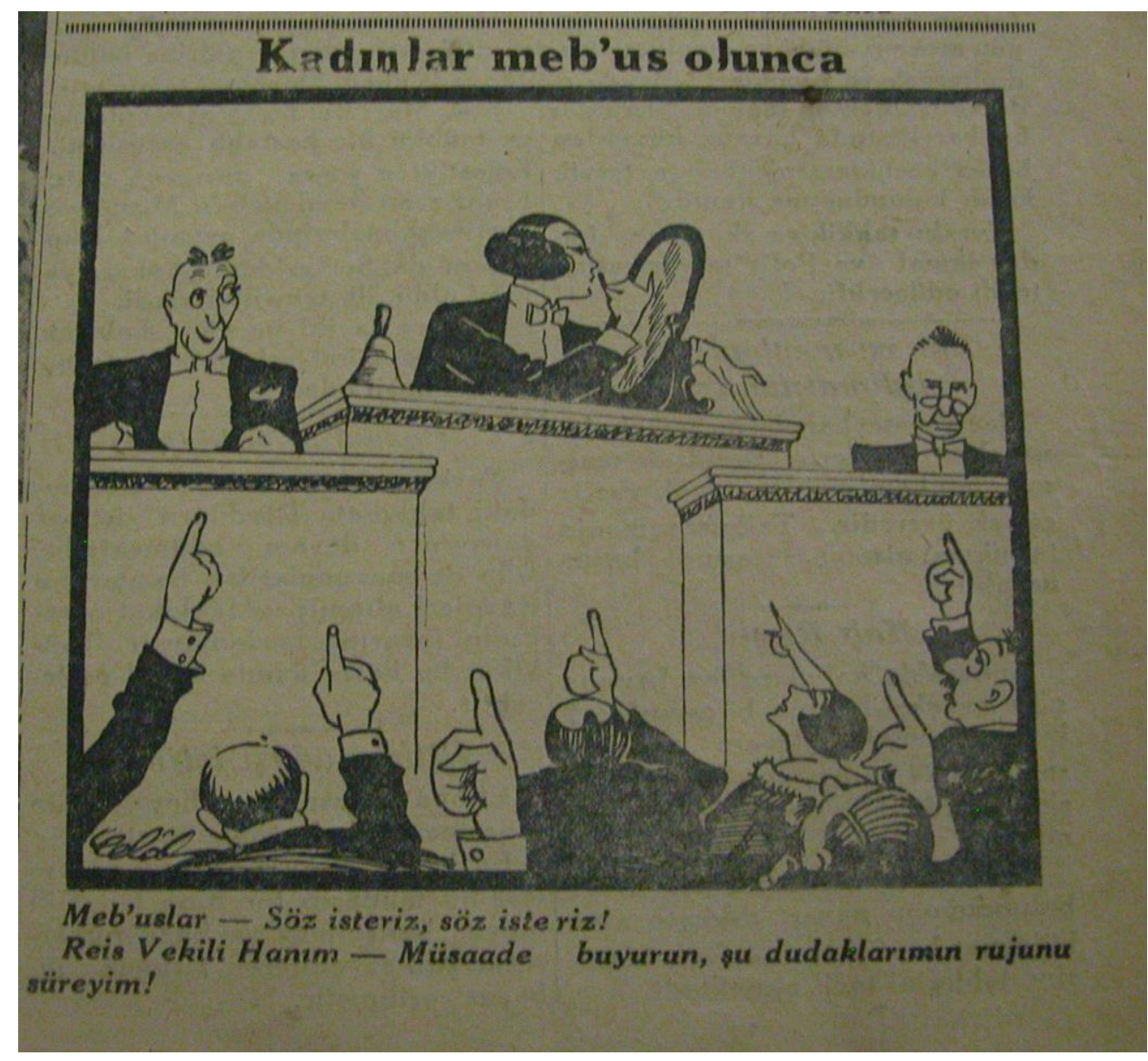

Figure 1: 31 March 1930, Cumhuriyet

Introductory caption: When women become deputies... 
The Parliament members: We want a word, we want a word! Mrs. Deputy President: Let me, let me put my lipstick!

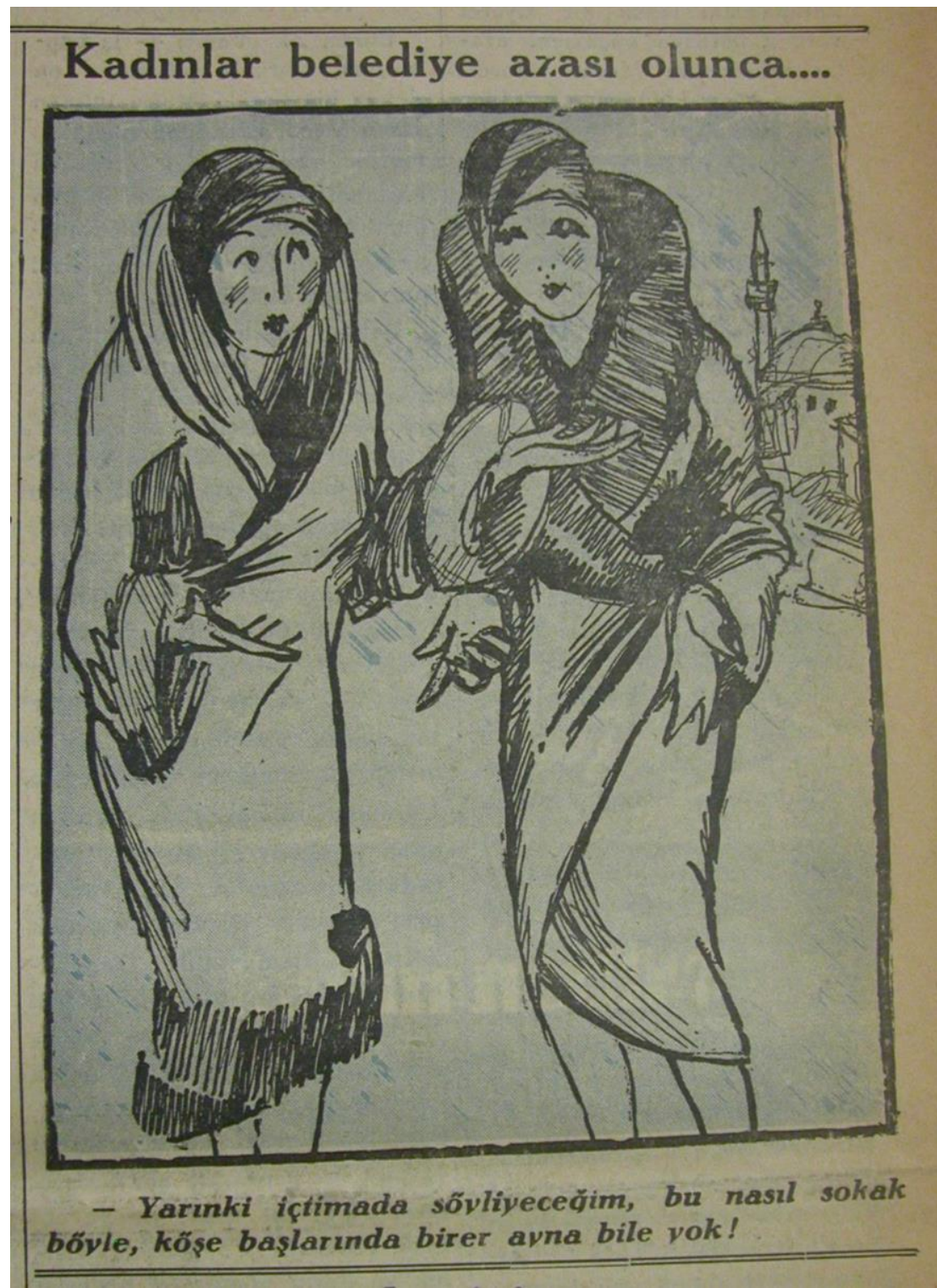

Figure 2: 25 March 1930, Vakit

Introductory caption: When women become members of municipal administration...

-I will say it at the assembly tomorrow, what kind of a street is that, there aren't even mirrors in the street corners!

These representations confine women's role to beauty and glamour and their role as an active individual is diminished to a "child-woman" who is expected to act according to her gender patterns and the realms of the patriarchal ideology instead of demanding to be an individual (see Zihnioğlu 2003, 227). Cartoons in figure 1 and 2 exemplify this description of woman. Mirror and lipstick are used as metaphors which denotatively identify women as feminine. Connotatively, the woman sitting in a serious position in figure 1 -as the chair of the parliamentary sessions- with a lipstick in her hand, symbolizes the incapacity of a woman handling serious "man" jobs. When one takes into account that a man would never be depicted with a shaver in his hand under these conditions, the sexist stereotyping of the cartoon could be understood better. Cartoons in these examples use all the tools of cartooning including exaggeration, infantilising and physiognomic stereotyping (Moloney et al. 2013, 287). They also refer to hetero-referential representations (Sen and Wagner 2005 cited by Moloney et.al. 2013) in which cartoon structures that implicitly or explicitly refer to two groups and foster one's own identity by setting up a boundary beyond which the other group is symbolically located (Moloney et al. 2013). The representation of woman as "child" fosters man representation as an "adult". The equation of women to "beauty" ascribes men the "potency" and the "ratio". The man sitting on the right side of the woman in figure 1 -with his glasses as a connotative symbol of seriousness- exemplifies this assumption. 
Hereto-referential representations also produce essentialist innuendos in which identities are circumscribed within fixed gender roles.

Cartoon, as a drawing using metaphors and symbols, enables the saying of the "unutterable" through ludicrous stereotyping. For instance it is one thing to write in a column that women's only feature is to become beautiful and their only function in life is to serve to the eyes of men but another thing to depict it via the power of the visual. Wekesa notes that

Cartoons (...) have an ethical imperative which lifts mere journalism into transcending art. Their method of affecting public opinion for the better course of human events qualifies them to make statements in pictures that would be considered false and too sensitive if they were verbal statements or in print. This means visuals have the ability to stretch the truth beyond caricature that obscures truth in the world of cartoons $(2012,237)$.

Sexist stereotyping of women endures in all cartoons including the one and only positive contented one. In figure 3 , a "contemporary" woman is depicted as climbing the ladders. Each stair refers to the rise of women socially, reaching better professions and social status. The caption reads a poem by Namik Kemal -a neo-Ottoman poet and journalistfostering women to rise more socially, claiming that she is not in the position she ought to be yet. Despite the "progressive" message in the cartoon, the depiction of the woman foments sexual innuendos in which physical feautures become prominent. Her bare legs and dress hold her rise hostage. This seems to be a caveat confining her status to her sex. In a transition period in which women have been ascribed the role of being the face of modernisation, her depiction as a "contemporary" woman -unveiled, with a low-cut dress leaving her legs bare-also indicates the social stances of the era. As printed records of history, cartoons can be interpreted as reflecting contemporary cultural attitudes and values, and serve to record and perpetuate commonly held beliefs (Giralli and Tulman 2003). 


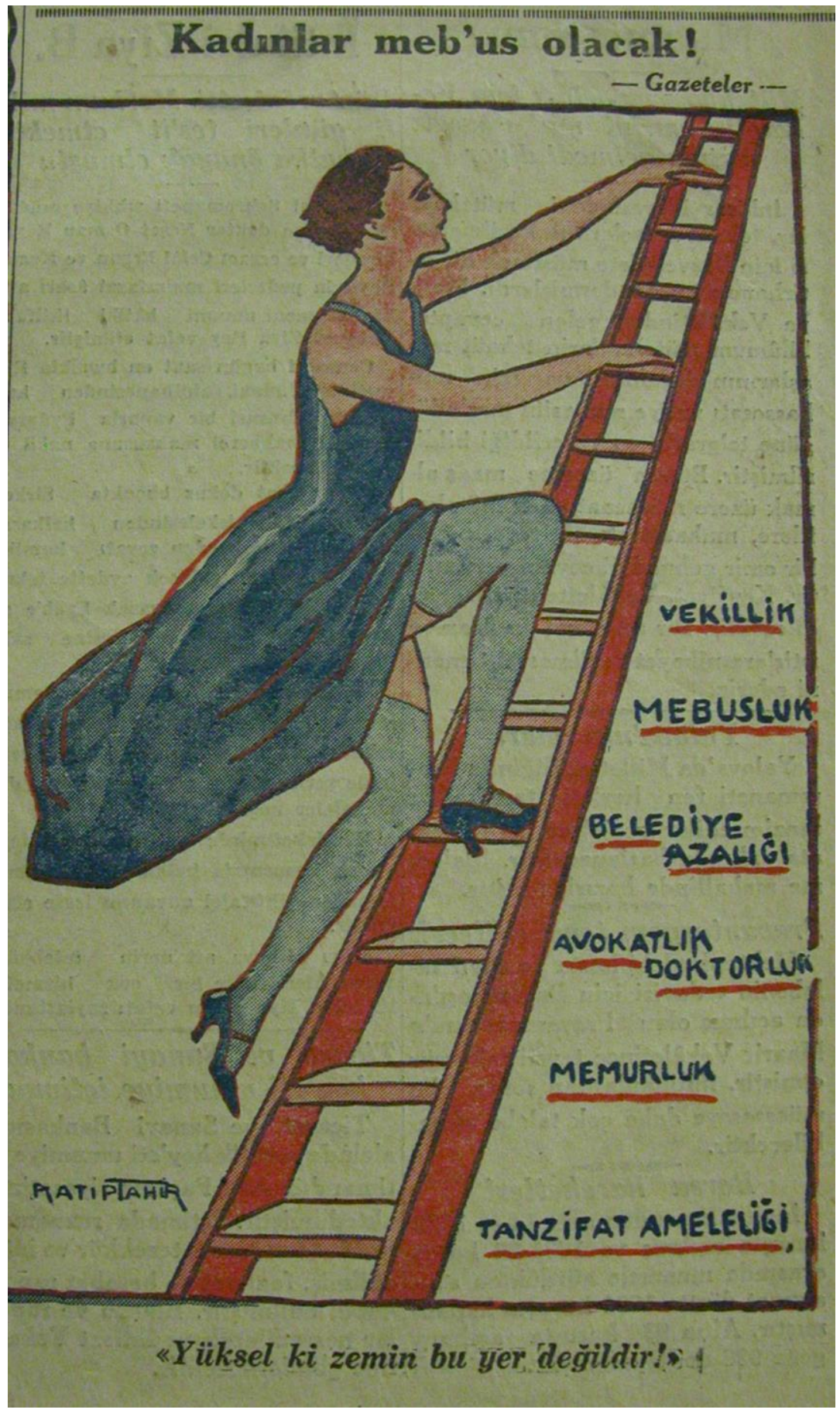

Figure 3: 26 March 1930, Cumhuriyet

Introductory caption: Women will become deputies! (Newspapers)

From bottom to top: street cleaning, public service, advocacy-doctorship, membership of municipal council, deputyship, membership of parliament

"Rise, this is not the place you ought to be!"

Another important aspect of women's representation in the cartoons is their depiction as "harridans", nagging, shouting or dominating men as shown in figure 4. They are described as "housewives" or "modern, contemporary" (asri) ladies who construe women's liberation as the subordination of men. This is the cliché of the "feminist" representation in which women are assigned neurotic images, bereft of sympathy. The "requiem" for male domination, the hidden wish to "preserve women's duties and reponsibilities in the household" (Ziya et. al. 2010) are reminders of the neo-patriarchy in which suffrage is coded as a loss in man's authority, including the household. 
Başaran İnce, G. / Journal of Yasar University, 2015 10(37) 6413-6431

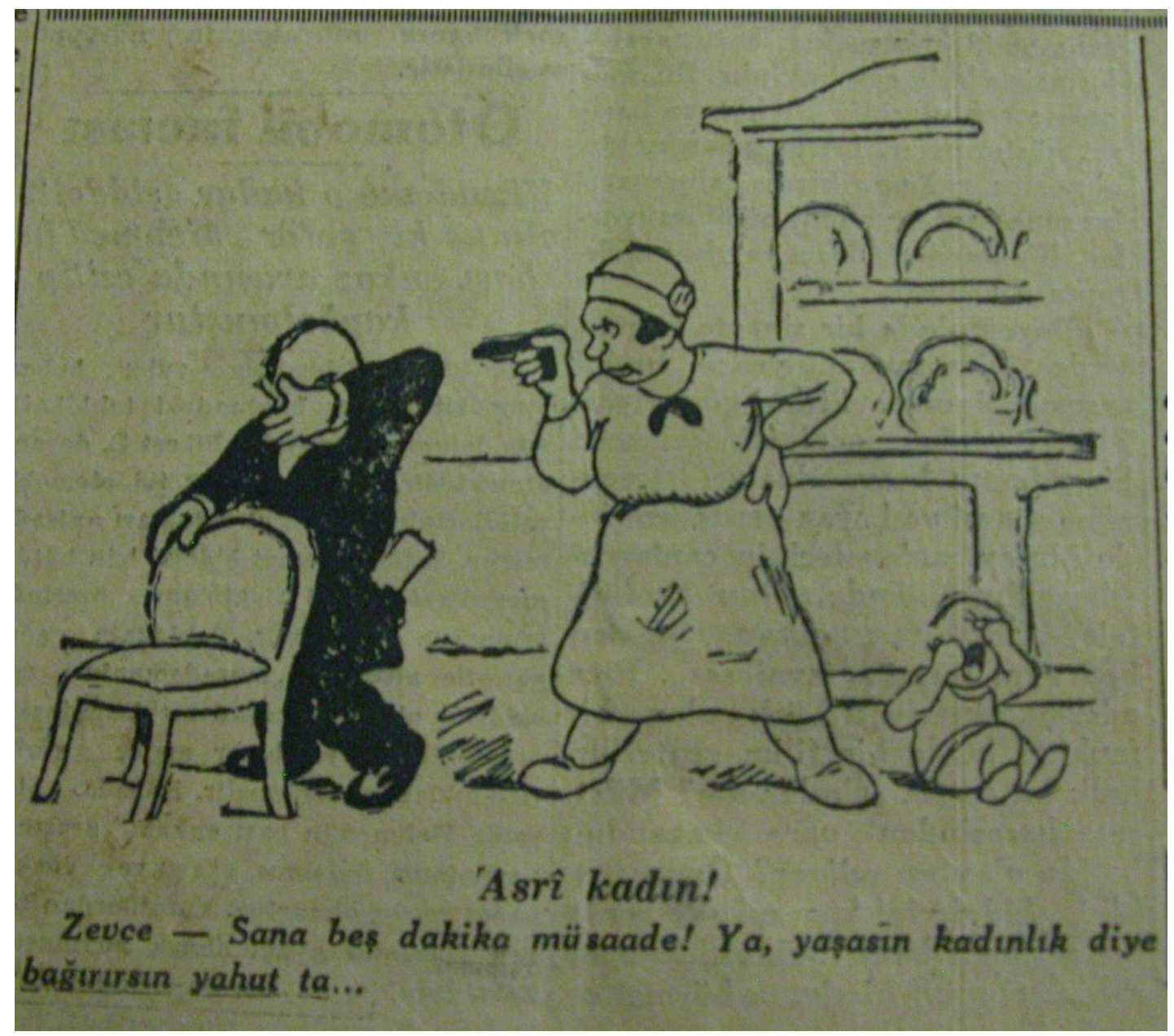

Figure 4: 24 March 1930, Cumhuriyet

Contemporary woman!

Wife-I give you five minutes! Either you shout as "long live the womenhood" or I will... 


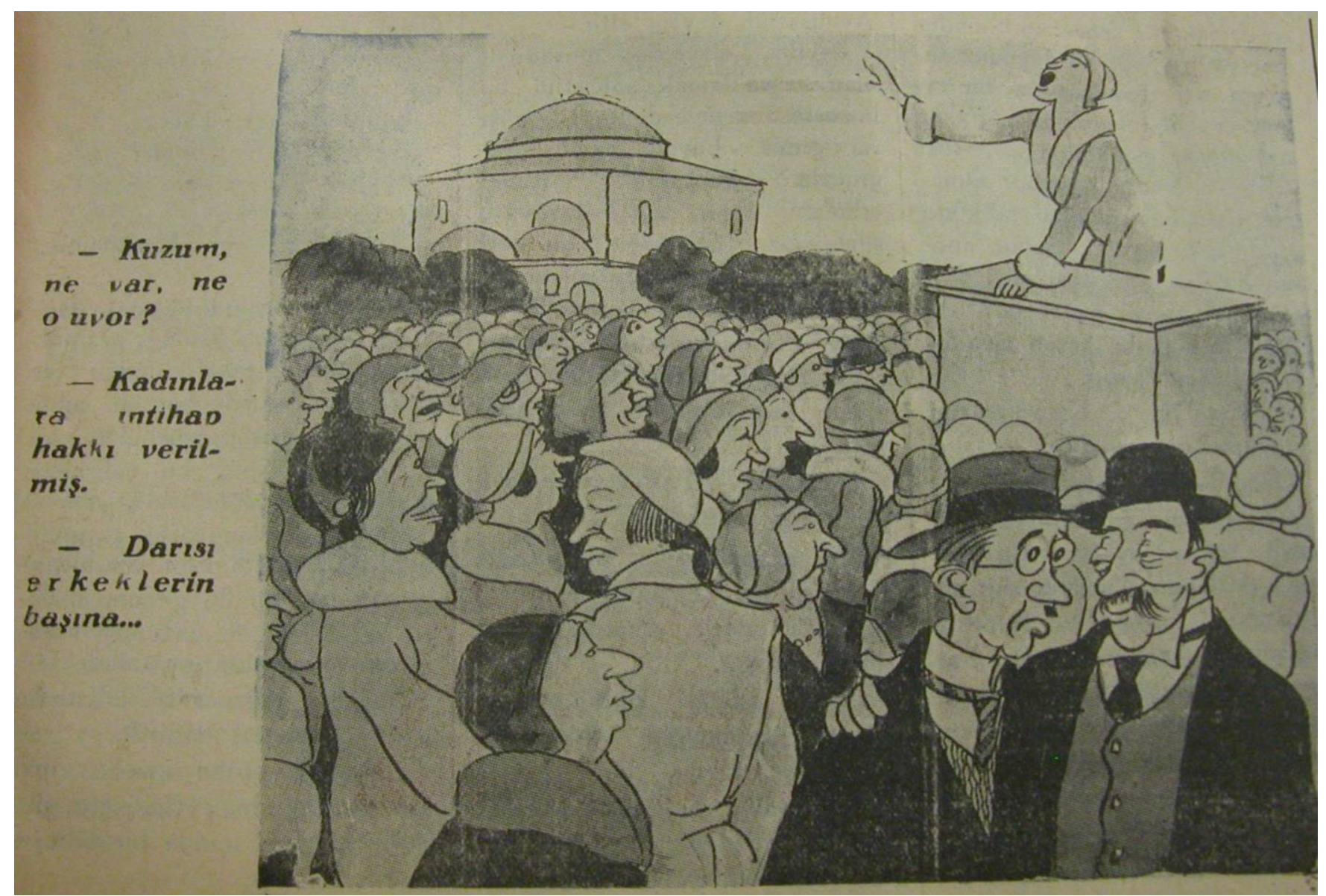

Figure 5: 4 April 1930, Vakit

\section{-Hey, what's up, what's going on? \\ -Women are granted suffrage. \\ -May our turn come next...}

Figure 5 also refers to this "requiem" through stereotypes. Stereotypes create fixed images of women and address the cultural memory of the society. They are easy and cliché representations that provide a "man's brotherhood" in which they are represented as the real "victims" and subordinates of womenhood. This is the reproduction of a widely shared common sense knowledge on women's dominance over men despite their lower status in the society. While humour is created by stereotypes, cartoons also become the sites of the conservative realm of meaning. Another important aspect of the cartoons is the usage of labels and captions which reinforce the meaning and the effect of the stereotypes. Cartoonists use captions “to complement and expand the imagery as well as to bracket the cartoon's range of interpretative readings" (Gencer 2012, 302).

\subsection{Cartoons on the Women's Union after the Granting of the Suffrage Rights}

Along with the granting of the suffrage rights, a dispute on the Women's Union inaugurates in the press, firstly condemning the Union for the unsuccesful meeting held to celebrate the electoral rights, then investigating the necessity of the Union after the granting of the rights. The Union's relationship with Nezihe Muhiddin also comes up in the newspapers. Muhiddin announces her ideas on the unnecessity of the Union and wants to deliver a speech at the meeting organised by the Union to celebrate the suffrage rights. In Milliyet, she explains her views as:

"I am one of the leading figures who struggled for women's rights. Who will stop me from addressing? I have not been planning to make a speech but now it is a matter of obstinacy. They do not put me on the list" ("Between Ladies", 10 April 1930, Milliyet).

\footnotetext{
${ }^{1}$ "Ben bu yolda mücadele eden, mücadele edenlerin başındayım. Kim hangi hakla benim söz söylememe mani olacak? Ben mutlaka bir şey söylemek fikrinde değildim. Fakat inat için söyleyeceğim. Beni listeye koymuyorlar."
} 
Efzayiş Suat from the executive committee of the Union answers to Muhiddin:

"The list of the names who will address at the meeting is decided. Miss Nezihe Muhiddin is not on the list and of course she can not say a word. If she insists, we will prevent her doing this with the authority ascribed to us by the Organising Committee. If Miss Nezihe is in need to deliver a speech, it is necessary for her to gather people whom will listen to her",2 (10 April 1930, Milliyet).

Milliyet covers this story with an illustration showing a black cat between Muhiddin and Latife Bekir (chair of the Union). On 12 April, Efzayiş Suat's picture delivering her speech is published. Next day, Muhiddin's views on the Women's Union are covered in the paper. The headline reads "Is there any need for the Women's Union any more?" and in the subtitle Muhiddin's words are placed: "There is no womens' union today, there is the union of the nation. We must lead all our efforts in the People's Party" (14 April 1930, Milliyet). Muhiddin blames the Union for the unsuccesful organisation where men attended the meeting more than the women. The dialogue between the correspondent and Muhiddin epitomises Muhiddin's views on women's struggle for rights and the road map for the future:

Correspondent: It is believed that you envy Union's success..

Muhiddin: Which success?! Despite my long time work, these ladies took over the organisation with fraud. It is my right to see the fruits of an organisation which I founded.

$C$ : Will you attempt to join Women's Union?

$M$ : No way, I would never like to work at an organisation like that.

$C$ : Do you think the Union is still needed for the defence of the women's rights?

M: The Government has started to sort out the gender differences and privilages one by one. The Civil Code equated men and women. The family decree has strengthened woman's position in the family. There is no need for a union to defend women. There is no women's union today. There is the union of the nation. There are no hindrances any more to do all our national duties in People's Party. The Women's Union has transformed to a charity organisation. Now Turkish woman has her rights. She receives the utmost respect. As for today, womens' struggle disappears automatically ${ }^{3}$ (14 April 1930, Milliyet).

Muhiddin's approachment to Kemalism is evaluated as an "'alleged' eulogy and compromise enabling her to publish her own version of the history of the women's movement" (Adak 2007, 43). Remembering her expel from the Union and the corruption charges about her, one may assume that she would have opposed the Republican People's Party but she thought that the only way to stay in politics would have been a reconciliation with the Party.

Along with this dispute between the Union and Nezihe Muhiddin, Milliyet publishes two portraitures of Latife Bekir and Efzayiş Suat. It is important to note that Muhiddin is depicted with real and likeable photographs unlike Bekir and Suat's caricatures. The choice of not depicting Muhiddin by caricature may indicate the relatively positive stance of the Paper about her. Comparing the depictions of Bekir, Suat and Muhiddin below substantiates the idea.

\footnotetext{
2 "Mitingte nutuk verecek hanımların isimleri tesbit olundu. Nezihe Muhiddin Hanım bu meyanda değildir. Ve bittabi söz söyleyemez. Mutlaka söylemek isterse, bu vaziyet program harici olduğu için buna tertip heyeti salahiyetini istimal ederek mani olacağı. Nezihe Hanım behemehâl söz söylemek ihtiyacında ise, etrafına kendini dinleyebilecekleri toplayarak bir miting yapması lazımdır."

${ }^{3}$ Muhabir: Birliğin muvaffakiyetini çekemiyormuşsunuz?

Muhiddin: Hangi muvaffakiyeti?! Birçok emeğim olduğu halde, bu kadınlar türlü hilelerle müessesesinin başına geçip kuruldular. Teşkil ettiğim bir cemiyetin semeresini görmek hakkımdır.

M: Kadın Birliği’ne girmeye teşebbüs edecek misiniz?

N.M: Kat'iyyen. Bu hale düşmüş bir cemiyette hiçbir zaman çalışmak istemem.

$M$ : Kadın hukukunu müdafaa için artık birliğe lüzum var mıdır?

N.M: Hükümet millet arasında cinsiyet farklarını, imtiyazları birer birer ayıklamağa başladı. Kanunu medeni kadınla erkeği müsavi bir hale getirdi. Aile kararnamesi, kadının aile arasındaki mevkiini tahkim etti. Kendi cinsini müdafaa edecek birliğe artık lüzum kalmamıştır. Bugün kadın birliği yoktur. Millet birliği vardır. Artık her milli işimizi, Halk Fırkasında görmemize hiçbir mani kalmamıştır. Kadın birliği artık yardım birliğine inkılap etmiştir. Bugün Türk kadını hukuna sahip bulunuyor. Azami hürmeti görüyor. Mesele bu safhaya dökülünce, kadın davası kendiliğinden ortadan kalkmıştır (14 April 1930, Milliyet).

At the end of the news, the newspaper notes that the correspondent has also attempted to speak to Latife Bekir (chair of the Union) but he/she was greeted "strangely" and Bekir said that she would not speak to the journalists.
} 
Başaran İnce, G. / Journal of Yasar University, 2015 10(37) 6413-6431

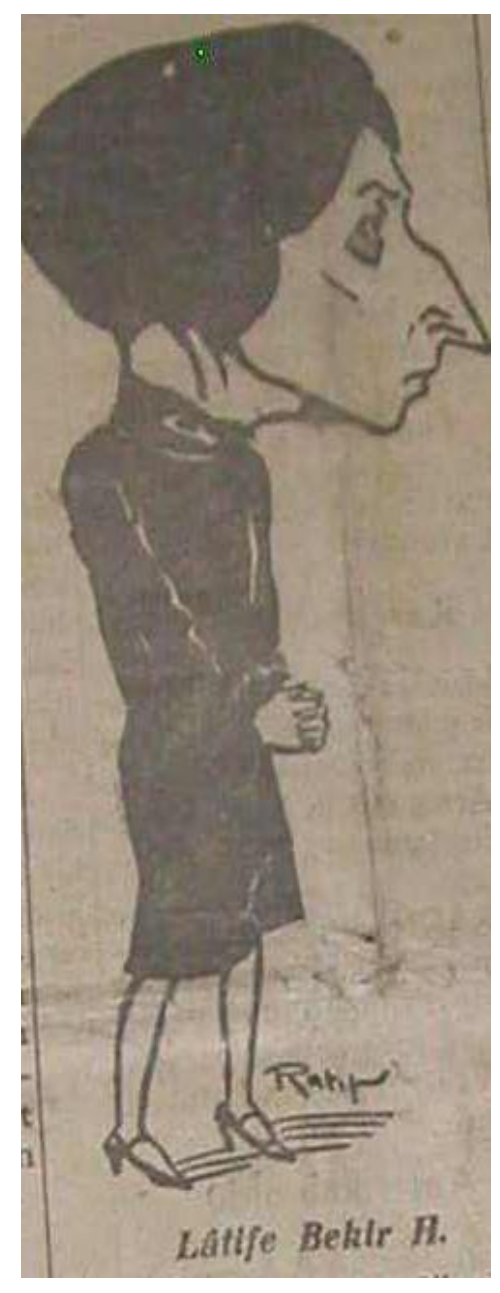

Figure 6: Latife Bekir

18 April 1930, Milliyet

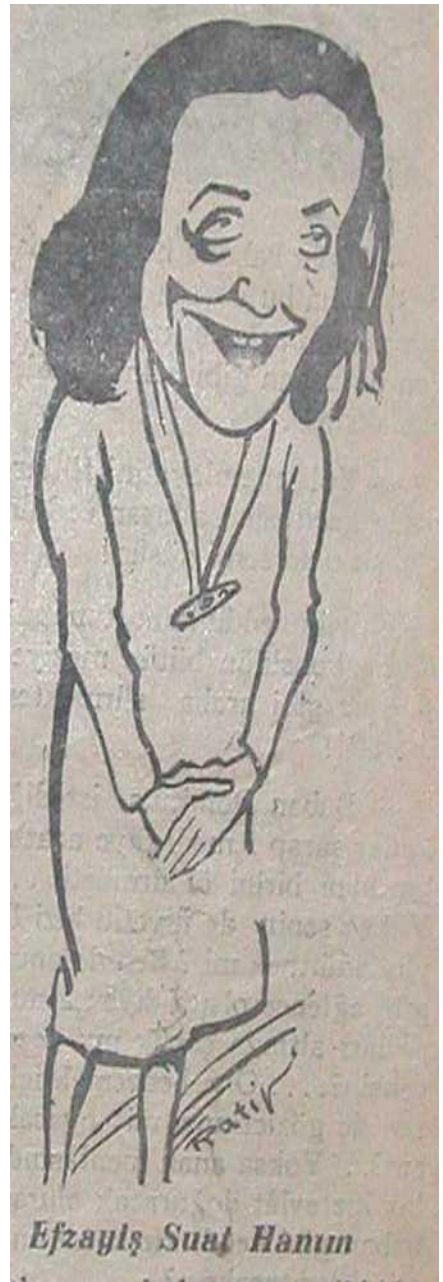

Figure 7: Efzayiş Suat

20 April 1930, Milliyet

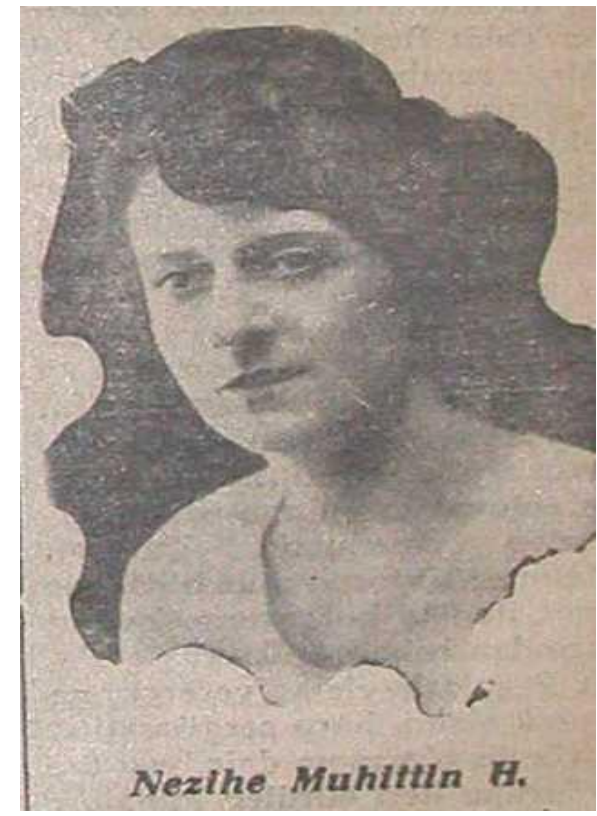

Figure 8: Nezihe Muhittin 


\section{March 1930, Milliyet}

In the cartoons, while Latife is depicted as a reticent, old and ugly lady and Efzayiş Suat like a half-mad person, Muhiddin's photograph is represented in a nostalgic aura, showing her young and beautiful. The news related to the cartoons of Latife and Efzayiş (figures 6-7) refer to the unsuccesful meeting held by the Women's Union and the Union's decision to transform to a charity organisation, their recourse to work in the Republican People's Party and their complaints about Muhiddin's attacks (18-20 April, Milliyet). The news about Muhiddin covers her recourse to the Party as a member with the photograph in figure 8 (27 March 1930, Milliyet). Milliyet's news coverage gives Muhiddin the chance to express her opinion on the future of the Union. For instance on 22 April 1930, Muhiddin articulates her ideas on the Union again:

"I did not say that there is no need for a women's union, I said that the Union as it is today should have been terminated. I still think that way. I think it is a ludicruous move to have recourse to the People's Party against me. Everbody can express his/her ideas freely in this country where there is the freedom of speech. As long as, these ideas are in favour of the country. The highest organisation of the country, the People's Party will certainly overcome such meaningless woman's gossip. These ladies are already used to complain. We want intellectual, reflective ladies in charge. Let them give us the conference hall of Darülfünun for once. Let Turkish women organise Women's Union again with their vote, their election. (...) Women's Union is a very important organisation (...) If it preserves itself as it is today and stays in the hands of ten incapable women gathered for gossip and personal interest, not only will it be ludicrous but also distance the whole womenhood from itself". 4

It is important to note that unlike Milliyet and Vakit, Cumhuriyet distances itself from the disputes on the Women's Union and Nezihe Muhiddin. The Paper stresses that Nezihe Muhiddin did not attend the celebration meeting on suffrage rights with a sub-title (12 April 1930, Cumhuriyet). The failure of the meeting is ascribed to the Union's unsuccessful organisation, yet in quotation marks, referring not to Muhiddin but to Nakiye Hanım ${ }^{5}$ as a "münevver and mütefekkir hanım" (an intellectual and reflective lady) (16 April Cumhuriyet). Nakiye Hanım's words are covered in the title as: "It is all the fault of the Women's Union" in quotations. The subtitle also reads "Why would our women who even join the wars, refrain from attending such a festival?"6 (16 April 1930, Cumhuriyet). Nakiye Hanım is not a name chosen by coincidence. In an interview in Vakit in May, Nakiye Hanım epitomises her views on the Union and suffrage rights as follows:

"I am not against the establishment of the Women's Union. But to me, an organisation like this has more important things to do then asking for suffrage rights. I think the Union must work in social fields rather than the political. Conference halls must be opened in various parts of the city. Here and at schools, our girls and our women must be illuminated on issues related to health and social matters. A mass of intellectual womenhood must be cultivated. Suffrage rights must not be demanded, they must be taken if they are given. Because as i said before, there are things to do before that""7 (25 May 1930, Vakit).

\footnotetext{
4 "Ben kadın birliğine ihtiyaç olmadığını değil, kadın birliğinin bugünkü vaziyetinde devamına nihayet verilmesi lazım geldiğini söylemiştim. Hala da aynı kanaattayım. Birliğin benim aleyhimde Halk firkasına müracaatını çok gülünç buldum. Hürriyeti kelam olan bu memlekette herkes serbestçe fikrini söyleyebilir. Yeter ki bu sözler memleketin hayrına matuf olsun. Halk firkası gibi memleketin en yüksek bir teşekkülü böyle manasız kadın dedikodularını elbette atlatacaktır. Bu hanımlar zaten șikâyete ezelden alıșıktıllar. Biz artık münevver, mütefekkir hanımlarımızın iş başına geçmesini, kadınlık aleminde hareketlerini görmek istiyoruz. Bize birgün Darülfünun konferans salonunu açsınlar. Türk kadınlığı kendi reyi, kendi intihabile kadın birliğini yeni baştan tesis etsin (...). "Kadın Birliği” çok ehemmiyetli bir teşekküldür. (...) Kadın birliği bugünkü halini muhafaza ettikçe ve sırf dedikodu, şahsi maksat için bir araya gelmiş on hanımın selahiyetsiz ellerinde kaldıkça gülünç olmakla kalmıyacak, bütün kadınlığı kendinden uzaklaştıracaktır". Here Muhiddin might be using the tactic of "positive propaganda" against the People's Party as Zihnioğlu refers (2003). In order to differentiate herself from the opponents of the Regime and endure the activities of the Union, Muhiddin generally presented herself as an "ally" of the Regime and its leaders.

${ }^{5}$ Nakiye (Elgün) Hanım is an educator who supported the National Independence War and the Kemalist movement by becoming active member of Türk Ocağı (Turkish Hearths), Halkevleri (People's Houses), Kızılay (Red Crescent) and Türk Hava Kurumu (Turkish Aviation Association). She was also the first woman member of Istanbul City Council in 1930 after the suffrage rights had been granted to women. She became the deputy of Erzurum after the attainment of electoral rights in general elections.

${ }^{6}$ Miting Niçin Muvaffak Olmadı? "Kabahat tamamile Kadın Birliğinin!...” Harbe bile şıtap eden kadınlarımız böyle bir bayramı tes'it etmekten neden kaçsınlar?"

7 "Kadınlar birliğinin teşekkülüne aleyhtar değilim. Fakat benim kanaatime göre, bu gibi bir teşekkülün intihap hakkı istemeden önce yapacağı diğer işler, daha mühim işler vardır. Bence birlik siyasi sahadan evvel içtimai sahada çalışmalı, şehrin muhtelif semtlerinde kadınlar için konferans salonları açılmalıdır. Buralarda ve mekteplerde kadınlarımız ve kızlarımız sıhhi, içtimai mevzularda tenvir edilmelidir. Münevver büyük bir kadınlık kütlesi yetiştirilmelidir. Siyasi hak istememeli, verilirse alınmalıdır. Çünkü dediğim gibi, daha evvel yapılacak işler vardır.”
} 


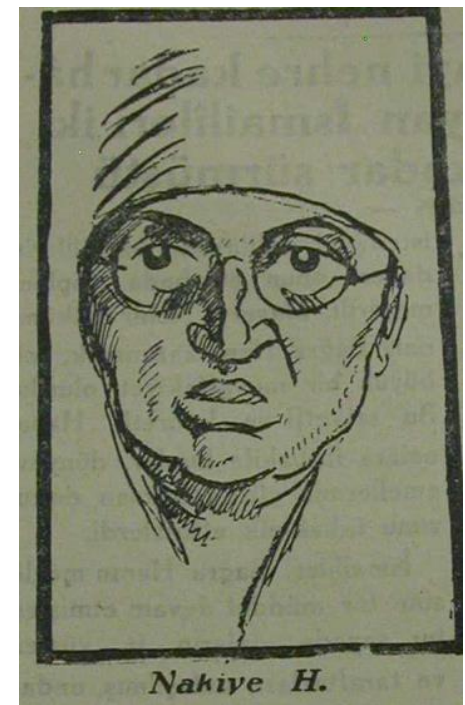

Figure 9:

25 May 1930, Vakit

A portraiture of Nakiye Hanım

In the following days, the Papers cover a dispute between Mazhar Osman (a well-known doctor of the era who established the first modern hospital of mental and neurological diseases in Turkey) and the Union (30 April 1930, Cumhuriyet and 25 May 1930, Vakit). Osman asserts that "the woman is a passive and weak creature that is created for reproduction"8 (30 April 1930, Cumhuriyet). On 1 May, Cumhuriyet brings the issue on the first page again under the title, "the Women's Union deplored Mazhar Osman!" 9 On the subtitle of the news, "a lady" from the Union substantiates the women's role as mothers: "We are not sure of the certainty of that article. Can one deny the right of motherhood?"10 (1 May 1930, Cumhuriyet). Vakit also brings the issue on the agenda again claiming that "Women of Izmir have responded to Mazhar Osman Bey" and adds Nakiye Hanım's ideas on the issue with the title that reads: "Are there women who agree with Mazhar Osman?" (25 May 1930). Nakiye Hanım disagrees with both Mazhar Osman and the Union claiming that the women should mind their own business. Her ideas on the Union and its mission that were epitomised above comes after this dispute (25 May 1930, Vakit).

Vakit also critisizes the Union for the unsuccesful meeting like Cumhuriyet, claiming that the number of men attended to the meeting had been more than the women. The Paper utters that the unsuccess of the meeting did also have "bad effects" (sui tesir) in Ankara. The correspondent visits the Union and expresses that the ladies in the Union had been "nervous" (asabi). An important detail is the division between the women of Ankara and Istanbul. The organisers from the Union blame the women of Ankara for not attending their meeting. The correspondent also asks Nezihe Muhiddin's views on the mission of the Union. Latife and Saime Hanım claim that Muhiddin does not have the right and authority to speak on the Union. But meanwhile Efzayiş Hanım enters the room and grabs Latife and Saime Hanım's arms and takes them out of the room, claiming that this issue makes her quiet nervous (The title and the subtitle reads: Nervosity at Women's Union, The Critisism of the Meeting Afflicted the Ladies!, They dont let mention Nezihe Muhiddin's name, 17 April 1930, Vakit) ${ }^{11}$.

Along with the granting of the suffrage rights, the sarcastic language of the news on the Union soars. The disputes between the women of the Union and Nezihe Muhiddin are covered as a "women's fight" in which the existence of the Union is questioned. These controversial relations are fomented by the cartoons of the leading leaders of the Union like Latife Bekir and Efzayiş Suat. On the contrary, Muhiddin is not depicted in the caricatures during these debates.

\section{Conclusion}

Analysing editorial political cartoons are of importance in order to penetrate to the cultural memory of societies and understand the attitudes toward social and political issues which are embodied in cultural artifacts. As Neighbor et al. notes

\footnotetext{
8 "Kadın infialine zebun, tenasül için yaratılmış pasif bir mahlûktur".

9 "Kadın Birliği Mazhar Osman Bey’e teessüf etti!".

10 "Bir hanım: Biz zaten o yazının kat'iyetinden emin değiliz. Kadınların analık hakkı inkâr edilebilir mi?" diyor".

11 "Kadın Birliğinde Asabiyet!, Miting Hakkındaki Umumi Tenkit Kadınları Mütessir Etmiş!, Nezihe Muhiddin H.ın ismini ağza aldırmıyorlar".
} 
Political cartoons are like time capsules; they provide viewers with a slice of life of the time in which they were created. Although they may seem locked in a given era as they refer to specific events, the themes expressed in cartoons are often universal, transcending time and place. Certain nuances of a cartoon may be lost in subsequent generations, such as language usage, popular references and out-dated symbols. However, changes in society and culture by no means render political cartoons obsolete. In fact, because of their editorial nature and mass appeal, cartoons provide a wealth of information about public sentiment and opinion, information often missing in scholarly accounts of historical events $(2014,16)$.

Cartoons analysed in this study also aim to understand the image of women in Turkey, a fastly modernising country where women were almost depicted as symbols or totems of modernisation (Ziya et. al. 2010, 312). Granting of the suffrage rights is an important issue, taking into account the tension between the women's movement and the Republican People's Party. The expel of Muhiddin from the Union, reestablishment of the Union as a charity organisation, the Republican People's Party becoming an authoritarian single-party system in which alternative modernisation discourses were marginalised, indicate the importance of scrutinising the women representation in the press after the granting of the suffrage rights.

The cartoons published during this period are replete with sexist clichés and stereotypes in which women are depicted as objects of beauty, bereft of reason and skill for professions that require sincerity like being deputy. Women are lampooned and mocked by the exaggeration of their gender characteristics which refer to sexist innuendos. The woman depiction in the cartoons also consists of "hetero-referential representations" which constitute an essentialist assessment of womenhood.

The cartoons/portraitures related to the Women's Union also depict the leading women of the era after the granting of the suffrage rights. Taking into account the sarcastic language of the news related to the Union and the portraitures, it is possible to say that the Union is held responsible for the unsuccesful meeting organised after the granting of the rights and its mission is questioned. Can one assume that the very existence of the Union starts to bother the political elites despite its "compromise" with the Regime on limiting the Union's activities to charity? It is difficult to infer the ideas of the elites from a limited data, yet it is possible to say that the stance of the newspapers toward the Union is negative. On the contrary, the depiction of Muhiddin in the news is relatively moderate. Taking into account the smear campaign launched against her in $1927^{12}$, during her expel from the Union, her depiction in 1930 seems to be less assaultive. Milliyet puts her views across on the Union, Vakit and Cumhuriyet report her criticism neutral. This rapid shift in the press' stance against Muhiddin reminds that her ideas on the Union may have been instrumentalised in order to question the mission of the Union and erode its reputation.

All in all, the cartoons on the women suffrage in Turkey reproduce the patriarchal image on women by vesting them with potency solely on "womanhood", confining their existence to their sexuality and questioning their abilities for "serious" men's professions. The leaders of the Women's Union are also lampooned by portraitures/caricatures, embodying the criticism toward the Union in themselves.

\section{REFERENCES}

Abraham, Linus. 2009. "Effectiveness of Cartoons as a Uniquely Visual Medium for Orienting Social Issues". Journalism and Communication Monographs 11(2): 117-165.

Adak, Hülya. 2007. "Suffragets of the Empire, Daughters of the Republic: Women auto/biographers Narrate National History." New Perspectives on Turkey 36: 27-51.

Al-Ali, Nadje.S. 2002. Women's Movements in the Middle East: Case Studies of Egypt and Turkey, UNRISD (United Nations Research Institute for Social http://eprints.soas.ac.uk/4889/2/UNRISD_Report_final.pdf date of access: December 2014

Anderson, Benedict. 2006. Imagined Communities. London: Verso.

Arat, Yeşim. 1996. On Gender and Citizenship in Turkey. Middle East Report, No: 198: $28-31$. http://www.merip.org/mer/mer198/gender-citizenship-turkey date of access: December 2014.

Arat, Yeşim. 1998. "Feminists, Islamists and Political Change in Turkey”. Political Psychology 19(1): 117-131.

Arat, Yeşim. 2001. "Women's Rights as Human Rights: The Turkish Case”. Human Rights Review 3(1): 27-34.

Arat, Zehra. 1994. "Turkish Women and the Republican Reconstruction of Tradition." In Reconstructing Gender in the Middle East: Tradition, Identity and Power, edited by Fatma Müge Göçek and Shiva Balaghi, 57-78. NY: Columbia University Press.

\footnotetext{
${ }^{12}$ Yunus Nadi from Cumhuriyet wrote about Muhiddin's expel from the Union in his coloumn with a headline which read: "Oh thank god, we are saved!’(Oh! Çok Şükür Kurtulduk!) (cited by Zihnioğlu 2003, 243). Milliyet even uttered about the foreign countries' influence during the disputes between the Union and Muhiddin and her expel from the Union ("Is it the foreign effect? Mrs. Nezihe finally resigned" (Ecnebi Parmağı mı? Nezihe Hanım nihayet istifa etti.) (25 September 1927, Milliyet, cited by Zihnioğlu 2003, 240).
} 
Atakav, A.Eylem. 2007. "Mona Lisa in Veils: Cultural Identity, Politics, Religion and Feminism in Turkey". Feminist Theology, 16: 11-20. DOI: 10.1177/0966735007082505

Barthes, Roland. 1977. Image, Music, Text. London: Fontana Press.

Beck, Lois. and Keddie, Nikkie. eds. 1978. Women in the Muslim World. Cambridge: Harvard University Press.

Bezirgan Arar, Yurdagül. 2010. "Haber Söyleminin Görsel Bir Formu Olarak Politik Karikatürün Ötekileştirme Pratiklerindeki İşlevi (The Functions of Political Cartoons as a Visual Form of News Discourse in Othering Practises)." Yeni Düşünceler 5 : 161-184.

Brockett, Gavin. 2011. How Happy to Call Oneself a Turk: Provincial Newspapers and the Negotiation of a Muslim National Identity. University of Texas Press.

Brummett, Palmira. 1995. "Dogs, Women, Cholera, and Other Menaces in the Streets: Cartoon Satire in the Ottoman Revolutionary Press, 1908-11”. International Journal of Middle East Studies 27(4): 433-460.

Caswell, Lucy S. 2004. "Drawing swords: war in American Editorial Cartoons". American Journalism 21(2): 13-45.

Cuff, Roger P. 1945. “The American Editorial Cartoon- A Critical Historical Sketch”. Journal of Educational Sociology 19(2):87-96.

Çeviker, T. 1997. Karikatür Üzerine Yazilar [Writings on Comic Art]. Istanbul: Iris Yayinlari.

Diner, Çağla and Toktaş, Şule. 2010. "Waves of Feminism in Turkey: Kemalist, Islamist and Kurdish Women's Movements in an Era of Globalization”. Journal of Balkan and Near Eastern Studies 12(1): 41-57. DOI: 10.1080/19448950903507388

Frantzich, Stephen. 2013. "Congress, The Houses of Ill Repute: Editorial Cartoonists Take on The House and Senate". Congress \& the Presidency, 40: 152-164, DOI: 10.1080/07343469.2013.783653

Gencer, Yasemin. 2012. "We are Family: The Child and Modern Nationhood in Early Turkish Republican Cartoons (1923-28)". Comparative Studies of South Asia, Africa and the Middle East 32(2): 294-309.

Gencer, Yasemin. 2013. "Pushing out Islam: Cartoons of the Reform Period in Turkey (1923-28)". In Visual Cultures in the Modern Middle East, edited by Christiane Gruber and Sune Haugbolle, 189-215. Indiana University Press.

Giarelli, Ellen and Tulman, Lorraine. 2003. "Methodological Issues in the Use of Published Cartoons as Data". Qualitative Health Research 13(7): 945-956. DOI: 10.1177/1049732303253545

Gökçimen, Semra. 2008. "Ülkemizde Kadınların Siyasal Hayata Katılım Mücadelesi”. Yasama 10: 5-59.

Guity, Novin. 2014. A History of Graphic Design, online book, http://guity-novin.blogspot.co.uk/2011/06/chapter-40history-of-caricatures.html, date of access: August 2014.

Kandiyoti, Deniz. 1987. "Emancipated but Unliberated? Reflections on the Turkish Case". Feminist Studies 13(2): 317338.

Kemnitz, Thomas Milton. 1973. "The Cartoon as a Historical Source”. The Journal of Interdisciplinary History 4(1): 81-93.

Kocabaşoğlu, Uygur. 1981-82. “1919-1938 Dönemi Basınına Toplu Bir Bakış”. Siyasal Bilgiler Fakültesi Basın Yayın Yüksek Okulu Yıllı̆̆g 6: 95-127.

Lawate, Meghana. 2012. "Importance of Political Cartoons to Newspapers". MA diss. Christ University. http://repository.christuniversity.in/1717/1/1024026_meghana lawate.pdf date of access: January 2015.

Moloney, Gail, Holtz, Peter and Wagner, Wolfgang. 2013. "Editorial Political Cartoons in Australia: Social Representations and the Visual Depiction of Essentialism". Integrative Psychological \& Behavioral Science 47(2):284-298.

Mulanda, Oliver and Khasandi-Telewa, Vicky. 2014. "In the Cartoonist's Mind: Exploring Political Comic Strips in Kenyan Daily Newspapers", The Journal of Pan African Studies 6(9): 30-43.

Neighbor, Tese.W., Karaca, Capri. and Lang, Kate. 2014. Understanding the World of Political Cartoons, https://www.world-affairs.org/wp-content/uploads/2013/10/2003-Understanding-Political-Cartoons.pdf date of access: December 2014

Özer, Sevilay. 2013. "Kadınlara Seçme ve Seçilme Hakkı Verilmesinin Türk Kamuoyundaki Yankıları”. Atatürk Araştırma Merkezi Dergisi 85: 131-167.

Safarian, Alexander. 2007. "On the History of Turkish Feminism”. Iran \& the Caucasus 11(1): 141-151.

Sen, Ragini and Wagner, Wolfgang. 2005. "History, emotions and hetero-referential representations in inter-group conflict: the example of Hindu-Muslim relations in India". Papers on Social Representations, 14: 2.12.23. http://psych1.1se.ac.uk/psr/PSR2005/14 02Sen.pdf date of access: December 2014

Toprak, Zafer. 1988. "Halk Fırkasından Önce Kurulan Parti: Kadınlar Halk Fırkası”. Tarih ve Toplum 51(9): 30-31.

Towns, Ann. 2014. "Carrying the Load of Civilisation: The Status of Women and Challenged Hierarchies", Millennium-Journal of International Studies 42(3): 595-613 DOI: 10.1177/0305829814533396

Tunç, Asl1. 2002. "Pushing the Limits of Tolerance: Functions of Political Cartoonists in the Democratization Process: The Case of Turkey". Gazette: The International Journal for Communication Studies 64(1): 47-62.

Vokey, Scott. 2000. "Inspiration for Insurrection or Harmless Humour? Class and Politics in the Editorial Cartoons of Three Toronto Newspapers during the Early 1930s". Labour/Le Travail 45: 141-170. 
Başaran İnce, G. / Journal of Yasar University, 2015 10(37) 6413-6431

Wekesa, Nyongesa Ben. 2012. "Cartoons Can Talk? Visual analysis of cartoons on the 2007/2008 post-election violence in Kenya: A visual argumentation approach". Discourse and Communication 6(2): 223-238. DOI: $10.1177 / 1750481312439818$

Zihnioğlu, Yaprak. 2003. Kadınsız İnkılap, İstanbul: Metis.

Ziya-Eslen, Hande ve Korkut, Umut. 2010. "Political Religion and Politicized Women in Turkey: Hegemonic Republicanism Revisited". Totalitarian Movements and Political Religions 11(3-4): 311-326, DOI: 10.1080/14690764.2010.546088. 